\title{
Lithologic Influence on the Hydrogeochemical Characteristics of Groundwater in Zango, North-west Nigeria
}

\author{
Amadi A.N. ${ }^{1, *}$, Tukur Aminu. ${ }^{2}$, Okunlola I. A. ${ }^{1}$, Olasehinde, P. I. ${ }^{1}$, Jimoh M.O. ${ }^{1}$ \\ ${ }^{1}$ Department of Geology, Federal University of Technology, Minna, Nigeria \\ ${ }^{2}$ Katsina State Rural Water Supply and Sanitation Agency, Nigeria
}

Copyright $(\underset{0}{2015}$ Horizon Research Publishing All rights reserved.

\begin{abstract}
The influence of bedrock on the quality of groundwater in Zango, North-west Nigeria was evaluated in this study. Water quality parameters such as $\mathrm{pH}$, electrical conductivity, temperature, total dissolved solids, nitrate, sulphate, chloride, phosphate, bicarbonate, fluoride, calcium, magnesium, potassium, sodium, iron, manganese, lead, zinc, cadmium, chromium and copper were used in assessing the impact of bedrock geochemistry on groundwater quality. Zango Local Government Area of Katsina State is underlain by Gundumi Formation, Chad Formation, Basement Complex Rocks and Younger Granites suites. The groundwater in the area shows characteristics signatures in major and elemental composition. Based on these signatures, the geochemical evolution of groundwater from the four different aquifer-types is quantitatively described by the interaction of the groundwater with the rock-forming minerals released into the groundwater system through natural processes of weathering and dissolution in the flow path. High concentration of fluoride, major and trace elements were observed in areas outcropped by Basement Complex Rocks and Younger Granites suites. The observed concentration ranges of fluoride, major and trace elements is a reflection of the natural background concentration and a landmark in geochemical characterization of groundwater from different aquiferous units. The result of the analysis is an indication that groundwater can be grossly contaminated by critical element. The concentration map developed for fluoride and other elements for the study was in agreement within the interpretation as the area dominated with sedimentary formations show low concentration while the region occupy by younger granites show high fluoride concentration. This implies that the granites in the area are composed of mineral containing these elements. Communities living in the granite/rhyolite dominated region where cases of fluorosis and heavy metal contamination have been observed should discontinue the use of groundwater from the area for domestic and drinking purposes. The Government should provide an alternative source of drinking water for the people.
\end{abstract}

Keywords Bedrock Influence, Hydrogeochemistry, Groundwater, Zango, North-west Nigeria

\section{Introduction}

The rock types in an area, particularly their weathered products and rainfall contribute greatly to the chemistry of groundwater. This in essence determines groundwater suitability for domestic, agricultural and industrial application. As groundwater migrates, it reacts with the minerals that make up the host-rocks. These mineral may be soluble and hence enrich the geochemical characteristics of the groundwater. Though groundwater is generally preferred to surface water because of its natural protection from pathogenic contamination and buffer against climatic variability, it can be grossly contaminated through natural processes such as chemical weathering and dissolution $[1,5]$.

According to [16], about $85 \%$ of communicable diseases are water borne or water related. Water is a universal solvent and natural resources tapped by man, animal and plants to meet their need on earth, either in vapour, liquid or solid form. The quality of groundwater of in area is a function of its chemistry and the nature of the aquifer characteristics [4]. Water is one of essential compounds for all forms of plants and animals, thus its pollution is generally considered more important than soil and air. The term heavy metal refers to metallic chemical elements that have relatively high density, toxic or poisonous at low concentration. They are natural components of the Earth's Crust that cannot be degraded or destroyed, and include the metals and metalloids. Some heavy metals are essential for life processes. Heavy metals such as $\mathrm{Cu}, \mathrm{Fe}, \mathrm{Mn}, \mathrm{Ni}$ and $\mathrm{Zn}$ are important in plants and micro-organisms as micronutrients and at low concentrations are essential for human health. Iron, for example, prevents anemia, and zinc is a cofactor in over 100 enzyme reactions. Studies revealed that $85 \%$ of all communicable diseases 
affecting humans are either water borne or water related [16]. However, some heavy metals such as $\mathrm{Cd}, \mathrm{Cr}$, and $\mathrm{Pb}$ have no known physiological activity, but they have proved detrimental beyond a certain limit. Diseases such as edema of eyelids, tumor, congestion of nasal mucous membrane and pharynx, stuffiness of head, gastrointestinal, muscular, cancer, reproductive, neurological and genetic malfunctions are caused by some of these heavy metals.

Heavy metals have therefore received considerable public attention from all over the world because of the concern that they will cause long-term damage to the environment and health and also due to their non-biodegradability [4]. There are problems of dental fluorosis in Zango area before now. Since there is no existing industry in the area, it suggests that the envisaged problem is rather geogenic than anthropogenic. The need to carry out a comprehensive and holistic assessment of groundwater quality in Zango and environs for domestic and other purposes gave rise to this study. The present study examines the impact of bedrock on the chemistry of groundwater from shallow aquifers in Zango area of North-west Nigeria.

\section{Geology of the Study Area}

Zango Local Government Area is located at the north-eastern part of Katsina State in North-west Nigeria on approximately between latitudes $12^{\circ} 50^{\circ} \mathrm{N}$ and $13^{\circ} 00^{\circ} \mathrm{N}$ of the Equator and between longitudes $8^{\circ} 26^{\circ} \mathrm{E}$ and $8^{\circ} 44^{\circ} \mathrm{E}$ of Greenwich Meridian (Figure 1). It is located about $100 \mathrm{Km}$ east of Katsina town and is accessible through a network of both tarred and untarred roads. It has an area of $601 \mathrm{~km}^{2}$ and a population of about 154,743 [11]. It is bounded in the north by Niger Republic, in the east by Baure Local Government Area, in the south by Jigawa State and in the west by Sandamu Local Government Area. Zango's uniqueness is extraordinary in the sense that it is the only local government area in Nigeria that is underlain by the following four different lithologies (Older Granites, Younger Granite/Rhyolites, Gundumi Formation and Chad Formation) as illustrated in figure 2 .

The latitudinal position of Katsina State and its interior location away from the sea determines the climate which is characterized by two main seasons (dry season from November to May and wet season from June to October). Therefore the climate is a hot one with maximum day temperatures reaching $38^{\circ} \mathrm{C}$ during the peak of the dry season. The area is affected by two wind patterns, the harmattan wind from the Sahara which is responsible for the cool months of December to February (about $24^{\circ} \mathrm{C}$ ) and the Southwest Monsoon Trade Winds blowing across the Atlantic Ocean which is responsible for the rains of June to October [13]. Average relative humidity is put at $42 \%$. Average rainfall is from about $800 \mathrm{~mm}$ to $1000 \mathrm{~mm}$ (Figure 1).

The area is predominantly Sudan Savanna which consists of scattered trees with sparse shrubs and grasses. The trees here grow long tap roots and thick barks that make it possible for them to withstand the long dry season. The grass too has long durable roots which remain underground after stalks are burnt away or wilted in the dry season only to germinate with the first rains. This area has been subjected to many years of bush-burning and over grazing. Trees such as Azadiracha Indica (Neem) and Parkia Biglobosa (Locust Bean) are now being planted to check against desert encroachment and erosion.

Reconnaissance survey was carried out on the study area in order to familiarize the area and identify the sampling points. This was followed by detailed geological and hydrogeological investigation of the area in which four main rock types were identified. The lithologies includes: the Gundumi Formation emanating from the Sokoto Basin, the Chad Formation which is part of the Chad basin as well as Granites and Rhyolites from the Basement Complex Rocks and Younger Granites suites (Figure 1). 


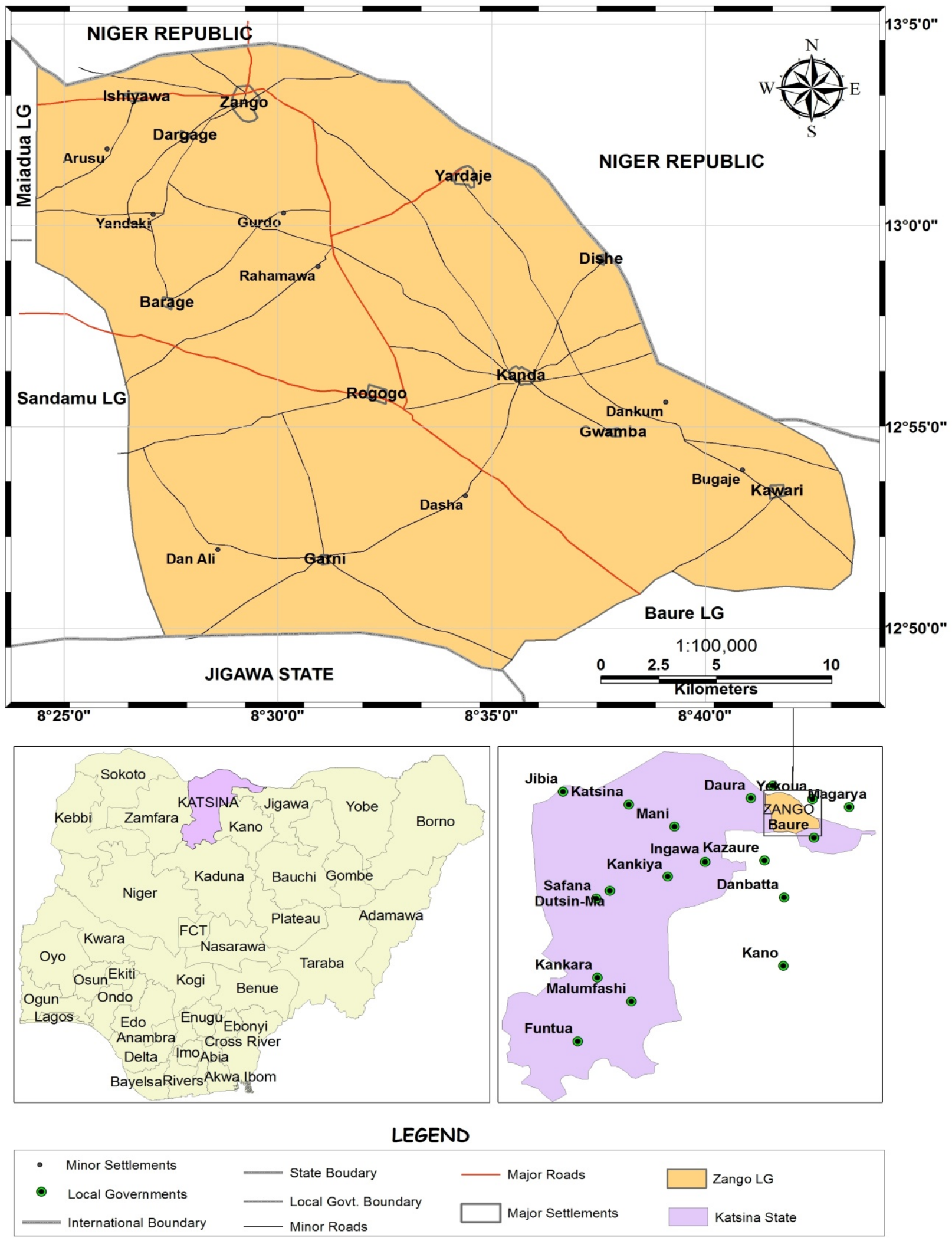

Figure 1. Map of Zango Local Government Area of Katsina State, North-west Nigeria 


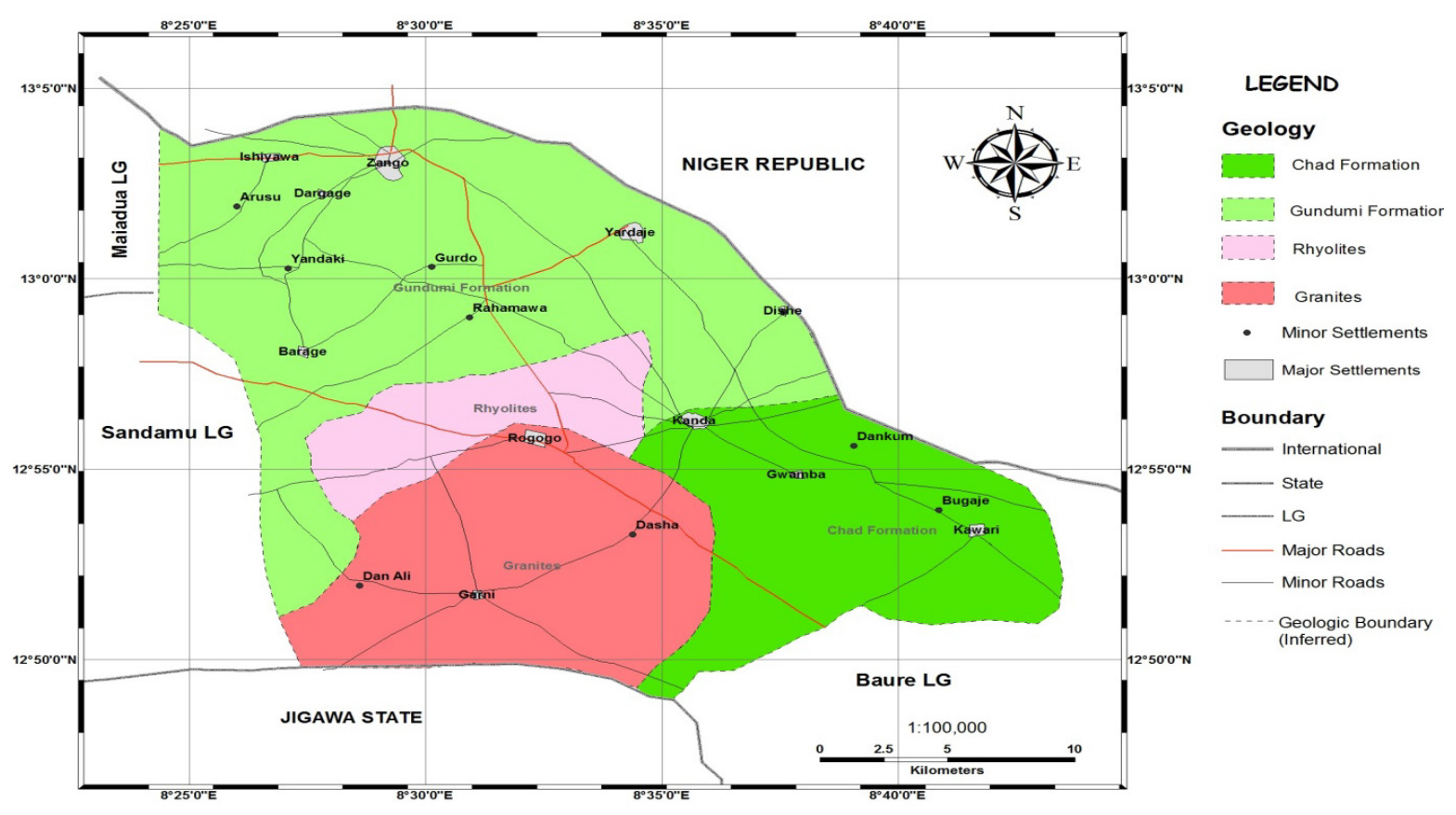

Figure 2. Geology Map of Zango Local Government Area of Katsina State, North-west Nigeria

\section{Materials and Methods}

Water Samples was collected across the entire local government area. Boreholes, hand-dug wells and solar powered water schemes were the sources that were sampled for this study. The sampling covers the Gundumi Formation emanating from the Sokoto Basin, the Chad Formation which is part of the Chad basin and the Basement Complex Rocks as well as the Younger Granites suites. A total of 87 water samples each were collected in the dry season and rainy season respectively. The measurement of the following physical parameter such as $\mathrm{pH}$, temperature, conductivity and turbidity were carried out in-situ (on site) using their appropriate instruments in line with the specified standards [6]. Glass and plastic containers were used to collect the samples at each location. Two drops of concentrated $\mathrm{HNO}_{3}$ were added to the water samples in the plastic container [14]. The water samples in the plastic containers were used for the determination of major cations and heavy metals while the water samples in the glass container are for the determination of the anions. At each sampling point, the longitude, latitude and elevation were taken with the aid of a global positioning system. All the analysis was analyzed at National Research Institute for Chemical Technology Laboratory Zaria, Nigeria. The determination of the physical parameters was carried out in the field using standard procedures while the analyses of chemical and bacteriological parameters were done in the laboratory. The physical parameters such as $\mathrm{pH}$, electrical conductivity (EC) and temperature were taken in-situ. Anions such as $\mathrm{SO}_{4}, \mathrm{PO}_{4}, \mathrm{NO}_{3}, \mathrm{HCO}_{3}$, and $\mathrm{Cl}$ were determined using titration method while fluoride was determined using colorimetric method. Concentration maps were plotted using the ArcGis version 9.3.

\section{Results and Discussion}

The statistical summary of the physico-chemical parameters of the groundwater analyzed are contained in Tables 1 and 2. The concentration of $\mathrm{pH}$ ranged between 5.15 to 7.85 with a mean value of 6.49 for the dry season and 5.70-7.55 with an average value of 6.48 for the rainy season. $\mathrm{pH}$ is an important indicator of water quality and extent of pollution. The mean $\mathrm{pH}$ values in both seasons fall below the universally acceptable range of $6.50-8.50[16,12]$. This implies that the $\mathrm{pH}$ in the study area is slightly acidic. This may be attributed to weathering and dissolution of the host rock (acidic granite). The concentration of electrical conductivity (EC) ranged from $22.70 \mu \mathrm{s} / \mathrm{cm}$ to 3050.00 $\mu \mathrm{s} / \mathrm{cm}$ with a mean value of $305.04 \mu \mathrm{s} / \mathrm{cm}$ for the dry season and $32.80 \mu \mathrm{s} / \mathrm{cm}$ to $3200.00 \mu \mathrm{s} / \mathrm{cm}$ with an average value of $980.85 \mu \mathrm{s} / \mathrm{cm}$ for the rainy season. The electrical conductivity is a valuable indicator of the amount of substances dissolved in water. The conductivity values in some locations on both seasons exceed the maximum permissible limit of $1000 \mu \mathrm{s} / \mathrm{cm}$ recommended by [17] and [12].

Areas of high conductivity coincide with the basement complex portion of the study area which comprises of granites and rhyolites. The groundwater in the area may have been enriched with ions from the host rock via weathering processes. Enrichment of groundwater by bicarbonate is mostly natural via bedrock dissolution due to the contact between groundwater and the host rock. The measured values are within the acceptable limit of [17] and [12]. The concentration of chloride in the groundwater ranges between 0.0 to $21.62 \mathrm{mg} / \mathrm{l}$ with a mean concentration of $7.21 \mathrm{mg} / \mathrm{l}$. These values fall significantly below the permissible limit of $250.0 \mathrm{mg} / 1[17,12]$. 
Table 1. Statistical summary of the physico-chemical and bacteriological parameters for dry season

\begin{tabular}{cccccccccc}
\hline Parameter & Max. & Min. & Mean & Range & Variance & S.D & M.D & Skew & Kurt \\
\hline $\mathrm{pH}$ & 7.85 & 5.15 & 6.489 & 2.70 & 0.373 & 0.611 & 0.489 & 0.238 & 0.354 \\
$\mathrm{EC}(\mathrm{us} / \mathrm{cm})$ & 3050 & 22.7 & 305.04 & 3027.3 & 22865 & 473.14 & 265.8 & 3.953 & 18.29 \\
$\mathrm{Cl}(\mathrm{mg} / \mathrm{l})$ & 21.62 & 0.00 & 7.208 & 21.62 & 25.599 & 5.06 & 4.073 & 0.557 & -0.07 \\
$\mathrm{HCO}(\mathrm{mg} / \mathrm{l})$ & 126 & 6.00 & 23.786 & 120 & 389.117 & 19.726 & 13.592 & 2.717 & 12.06 \\
$\mathrm{~F}(\mathrm{mg} / \mathrm{l})$ & 3.16 & 0.10 & 0.806 & 7.06 & 0.813 & 0.902 & 0.696 & 1.523 & 1.261 \\
$\mathrm{Ca}(\mathrm{mg} / \mathrm{l})$ & 127.82 & 0.06 & 5.815 & 127.76 & 240.026 & 15.493 & 6.712 & 6.721 & 51.85 \\
$\mathrm{Mg}(\mathrm{mg} / \mathrm{l})$ & 3.19 & 0.00 & 1.714 & 3.19 & 1.44 & 1.20 & 1.11 & 0.229 & 1.613 \\
$\mathrm{Na}(\mathrm{mg} / \mathrm{l})$ & 31.18 & 0.07 & 6.791 & 31.11 & 48.758 & 5.863 & 5.832 & 1.135 & 0.75 \\
$\mathrm{~K}(\mathrm{mg} / \mathrm{l})$ & 28.22 & 0.19 & 8.347 & 28.03 & 39.376 & 6.275 & 5.047 & 0.996 & 0.758 \\
$\mathrm{Mn}(\mathrm{mg} / \mathrm{l})$ & 0.48 & 0.01 & 0.091 & 0.47 & 0.012 & 0.111 & 0.089 & 1.525 & 1.92 \\
$\mathrm{Fe}(\mathrm{mg} / \mathrm{l})$ & 0.30 & 0.01 & 0.122 & 0.01 & 0.006 & 0.08 & 0.06 & 1.366 & 3.994 \\
$\mathrm{Cu}(\mathrm{mg} / \mathrm{l})$ & 0.08 & 0.01 & 0.041 & 0.07 & 0.0005 & 0.022 & 0.018 & 0.174 & -1.03 \\
$\mathrm{Cr}(\mathrm{mg} / \mathrm{l})$ & 0.10 & 0.01 & 0.029 & 0.09 & 0.0005 & 0.022 & 0.029 & 1.377 & 1.252 \\
$\mathrm{~Pb}(\mathrm{mg} / \mathrm{l})$ & 0.05 & 0.01 & 0.017 & 0.04 & 0.0001 & 0.011 & 0.008 & 1.884 & 3.245 \\
$\mathrm{SO}{ }_{4}(\mathrm{mg} / \mathrm{l})$ & 78.65 & 0.06 & 11.688 & 78.59 & 275.912 & 16.611 & 11.021 & 2.633 & 7.428 \\
$\mathrm{NO}{ }_{3}(\mathrm{mg} / \mathrm{l})$ & 19.12 & 0.06 & 6.279 & 18.52 & 21.144 & 4.598 & 3.801 & 0.73 & -0.23 \\
$\mathrm{PO}(\mathrm{mg} / \mathrm{l})$ & 9.40 & 0.01 & 1.744 & 9.39 & 4.021 & 2.005 & 1.564 & 1.688 & 2.96 \\
\hline
\end{tabular}

Table 2. Statistical summary of the physico-chemical and bacteriological parameters for rainy season

\begin{tabular}{cccccccccc}
\hline Parameters & Max. & Min. & Mean & Range & Variance & S.D & M.D & Skew & Kurt \\
\hline $\mathrm{pH}$ & 7.55 & 5.70 & 6.475 & 1.85 & 0.454 & 0.674 & 0.556 & 0.656 & -1.01 \\
$\mathrm{EC}(\mathrm{us} / \mathrm{cm})$ & 3200 & 32.80 & 980.85 & 3167.2 & 1161.669 & 1077.8 & 822.08 & 1.627 & 1.88 \\
$\mathrm{Cl}(\mathrm{mg} / \mathrm{l})$ & 13.37 & 3.45 & 6.544 & 9.92 & 12.816 & 3.58 & 2.93 & 1.087 & 0.317 \\
$\mathrm{HCO}(\mathrm{mg} / \mathrm{l})$ & 135 & 12.00 & 57.00 & 123.00 & 4599 & 50.974 & 35.76 & 2.03 & 4.211 \\
$\mathrm{~F}(\mathrm{mg} / \mathrm{l})$ & 1.47 & 0.10 & 0.523 & 1.37 & 0.205 & 0.453 & 0.333 & 1.432 & 2.234 \\
$\mathrm{Ca}(\mathrm{mg} / \mathrm{l})$ & 10.95 & 0.03 & 4.149 & 10.92 & 10.355 & 3.218 & 2.116 & 1.297 & 3.005 \\
$\mathrm{Mg}(\mathrm{mg} / \mathrm{l})$ & 14.9 & 0.32 & 11.82 & 14.47 & 25.716 & 5.071 & 3.633 & -2.11 & 4.372 \\
$\mathrm{Na}(\mathrm{mg} / \mathrm{l})$ & 25.39 & 3.70 & 13.108 & 21.69 & 57.698 & 7.596 & 6.283 & 0.464 & -1.15 \\
$\mathrm{~K}(\mathrm{mg} / \mathrm{l})$ & 26.91 & 0.28 & 11.114 & 26.63 & 112.655 & 10.614 & 9.415 & 0.64 & -1.83 \\
$\mathrm{Mn}(\mathrm{mg} / \mathrm{l})$ & 0.02 & 0.01 & 0.015 & 0.01 & 3.333 & 0.006 & 0.005 & -1.18 & -6.00 \\
$\mathrm{Fe}(\mathrm{mg} / \mathrm{l})$ & 0.02 & 0.03 & 0.139 & 0.17 & 0.003 & 0.054 & 0.037 & -1.18 & 1.766 \\
$\mathrm{Cu}(\mathrm{mg} / \mathrm{l})$ & 0.02 & 0.01 & 0.016 & 0.01 & 2.679 & 0.005 & 0.005 & -0.64 & -2.24 \\
$\mathrm{Cr}(\mathrm{mg} / \mathrm{l})$ & 0.07 & 0.01 & 0.031 & 0.06 & 0.0005 & 0.022 & 0.019 & 0.615 & -0.73 \\
$\mathrm{~Pb}(\mathrm{mg} / \mathrm{l})$ & 0.06 & 0.01 & 0.02 & 0.05 & 0.0004 & 0.019 & 0.014 & 1.994 & 3.694 \\
$\mathrm{SO}(\mathrm{mg} / \mathrm{l})$ & 110.0 & 1.00 & 27.75 & 109.00 & 1552.21 & 39.398 & 29.688 & 1.629 & 2.076 \\
$\mathrm{NO}{ }_{3}(\mathrm{mg} / \mathrm{l})$ & 19.40 & 1.80 & 7.90 & 17.60 & 35.617 & 5.968 & 4.625 & 1.07 & 0.608 \\
$\mathrm{PO}{ }_{4}(\mathrm{mg} / \mathrm{l})$ & 55.53 & 0.53 & 9.463 & 55.00 & 358.256 & 18.928 & 11.944 & 2.66 & 7.197 \\
\hline
\end{tabular}

Max- maximum; Min- minimium; SD- standard deviation; MD- mean deviation;

EC- electrical conductivity; Kurt- kurtosis; Skew- skewness 
High chloride content in groundwater may indicate pollution by sewage, effluent or marine source $[2,9]$. Although the chloride concentrations in the area are within the recommended value, the highest values fall within the granite and rhyolite region, an indication of geogenic source. The concentration of chloride in the groundwater ranges between 0.0 to $21.62 \mathrm{mg} / \mathrm{l}$ with a mean concentration of 7.21 $\mathrm{mg} / \mathrm{l}$. These values fall significantly below the permissible limit of $250.0 \mathrm{mg} / 1$ [16, 12]. High chloride content in groundwater may indicate pollution by sewage, effluent or marine source $[2,3,9]$. Although the chloride concentrations in the area are within the recommended value, the highest values fall within the granite and rhyolite region, an indication of geogenic source. The concentration of sulphate varied from 0.06 to $78.65 \mathrm{mg} / \mathrm{l}$ with an average value of $11.69 \mathrm{mg} / \mathrm{l}$ while the concentration of nitrate ranged between 0.60 to $19.12 \mathrm{mg} / \mathrm{l}$ and a mean value of $6.30 \mathrm{mg} / \mathrm{l}$. The value of phosphate ranged between $0.01 \mathrm{mg} / \mathrm{l}$ to $9.40 \mathrm{mg} / \mathrm{l}$ with a mean value of $1.74 \mathrm{mg} / \mathrm{l}$. The concentration of potassium ranged between $0.19 \mathrm{mg} / \mathrm{l}$ to $28.22 \mathrm{mg} / \mathrm{l}$ while the concentration of sodium varied between $0.07 \mathrm{mg} / \mathrm{l}$ to 31.18 $\mathrm{mg} / \mathrm{l}$. The concentration of magnesium falls between 0.0 to $3.19 \mathrm{mg} / \mathrm{l}$ while calcium has values ranged between $0.03 \mathrm{mg} / \mathrm{l}$ to $10.95 \mathrm{mg} / \mathrm{l}$ with a mean value of $4.15 \mathrm{mg} / \mathrm{l}$. The concentrations of the cations are within the acceptable limit of Nigerian Standard for Drinking Water Quality. Studies by [3] revealed that magnesium in water is better and easily absorbed than dietary magnesium. Calcium is necessary in animals for the formation of strong teeth and bones. There is some evidence to show that the incidence of heart disease is reduced in areas served by a public water supply with a high degree of hardness, the primary constituent of which is calcium [10].

Fluoride content in groundwater of the area ranged between 0.10 to $3.16 \mathrm{mg} / \mathrm{l}$ with a mean value of $0.94 \mathrm{mg} / \mathrm{l}$ for dry season and between 0.10 to $1.47 \mathrm{mg} / \mathrm{l}$ and an average value of $0.52 \mathrm{mg} / \mathrm{l}$ for the rainy season. The low concentration of fluoride in the rainy season is due to the dilution effect of rain-water. The study revealed that about $75 \%$ of the groundwater samples in the area that are suitable for human consumption fall within the sedimentary rocks of the Gundumi and Chad Formations as well as the Basement Complex rocks while $25 \%$ of the samples with high fluoride concentration above the permissible limit of $1.5 \mathrm{mg} / \mathrm{l}$ are from the Younger Granites Suites. Fluorite, a hydrothermal mineral in granite and due to its fast dissolution kinetics, is probably the source of fluoride in the groundwater in the area. This implies that fluoride-rich groundwater in the area emanates from the granite aquifers and the problem of fluorosis in the area is purely by natural processes through weathering of fluorite mineral contained in the host rock [7, $8,4]$. High concentration of fluoride in ground water causes a disease known fluorosis which affects mainly the teeth and bones and evidence of dental fluorosis have been observed in Zango area already (Plates 1 and 2) and this is part of what necessitated this research and also lead to the generation of fluoride concentration map of Zango area (Figure 3). This serves as reference points and baseline information for metallic and fluoride contamination of groundwater system in Zango area of Katsina State. These findings suggest that the enrichment factor of the ions on the groundwater is possibly geogenic mean and related to the local geology of the area. The alkaline $\mathrm{pH}$ and high bicarbonate are responsible for release of fluoride-bearing minerals into groundwater. Heavy Metals are metallic elements that have a relatively high density and are toxic at very low concentration. It refers to chemical elements with a specific gravity that is at least 5 times the specific gravity of water. The concentration of manganese ranged from $0.01-0.48 \mathrm{mg} / 1$ with a mean concentration of 0.09 and $0.01-0.02 \mathrm{mg} / 1$ with an average value of $0.015 \mathrm{mg} / \mathrm{l}$ for the rainy season. Some locations in dry season exceed the maximum permissible limit of $0.2 \mathrm{mg} / 1[12,16]$. The concentration of iron in the dry season varied from $0.01-0.20 \mathrm{mg} / 1$ with an average concentration of $0.12 \mathrm{mg} / \mathrm{l}$ and between $0.03-0.20 \mathrm{mg} / \mathrm{l}$ with a mean value of $0.14 \mathrm{mg} / \mathrm{l}$ for the rainy season. These concentrations are within the recommended limit of 0.03 $\mathrm{mg} / \mathrm{l}(12,17]$. The human body needs iron for basic metabolic activities as it is a useful ingredient of the blood. Insufficient iron in the body causes goitre. Iron infiltrates into the groundwater as a result of chemical weathering of rock/laterilization. It is responsible for the reddish-brown colour in laterites. The concentration of copper varied from $0.01-0.08 \mathrm{mg} / \mathrm{l}$ with a mean value of $0.04 \mathrm{mg} / \mathrm{l}$ during the dry season and between $0.01-0.02 \mathrm{mg} / \mathrm{l}$ with an average value of $0.016 \mathrm{mg} / \mathrm{l}$.

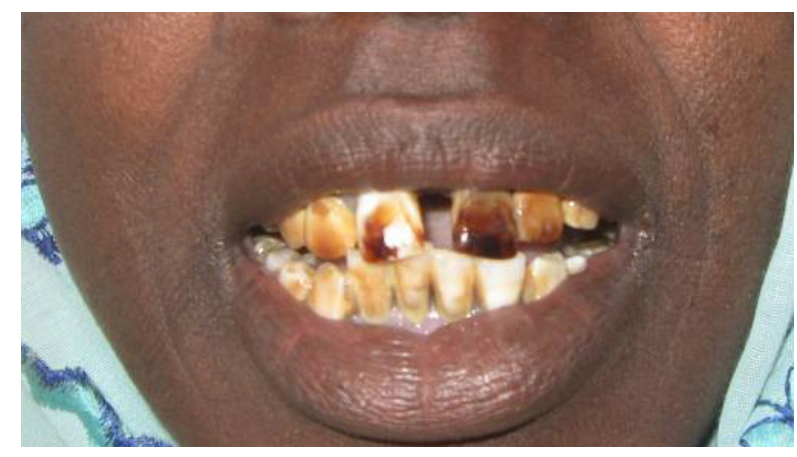

Plate 1. Dental Fluorosis observed in the southern part of Zango LGA (Kasuwayal, Area)

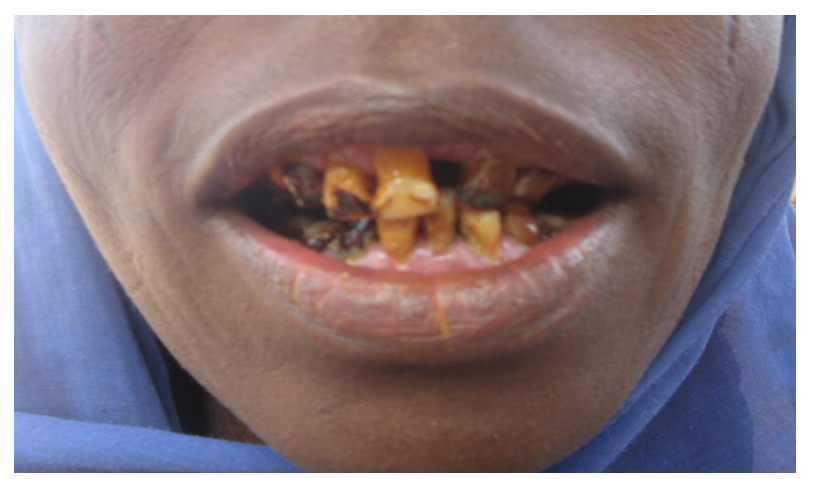

Plate 2. Dental fluorosis observed in the central part of Zango LGA (Jama'ar-Malam Area) 


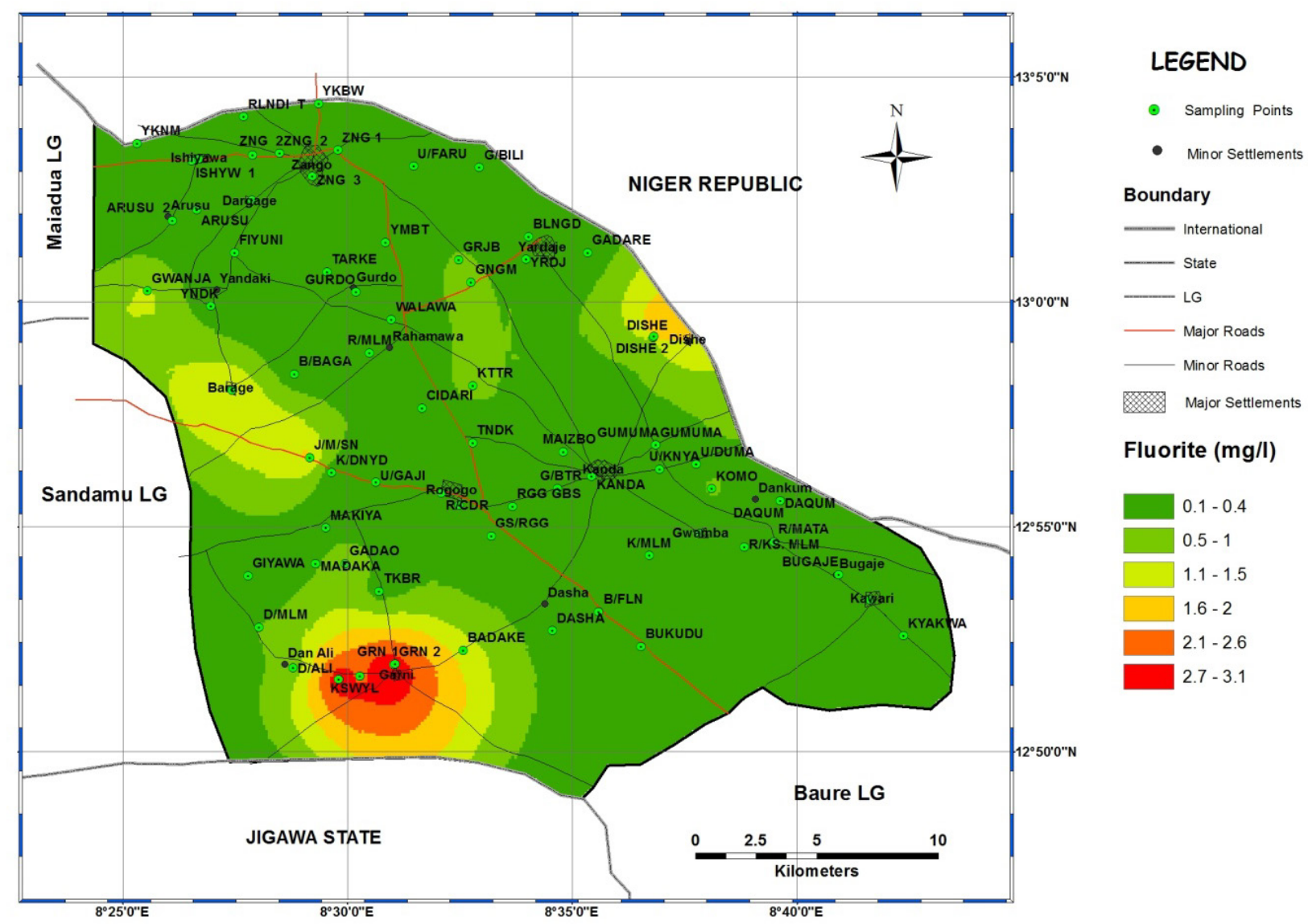

Figure 3. Fluoride concentration map of Zango Local Government Area of Katsina State

These concentrations fall below the maximum permissible limit of $1.0 \mathrm{mg} / 1$ [12]. Copper enrichment in drinking water can result in gastrointestinal disorder in human [15]. The concentration of chromium ranged between $0.01-0.10 \mathrm{mg} / \mathrm{l}$ and $0.01-0.07 \mathrm{mg} / 1$ for dry and rainy season respectively. The concentration of rainy season sampling in few places exceeds the maximum permissible limit of $0.05 \mathrm{mg} / 1$ [12]. Chromium is naturally occurring element in rocks, but toxic at elevated concentrations and causes cancer [15]. The concentration of lead ranged between $0.01-0.05 \mathrm{mg} / \mathrm{l}$ for dry season and $0.01-0.06 \mathrm{mg} / \mathrm{l}$ for rainy season. The mean concentrations are $0.017 \mathrm{mg} / \mathrm{l}$ and $0.02 \mathrm{mg} / \mathrm{l}$ for dry and rainy seasons respectively. The mean concentration exceeds the maximum permissible limit of $0.01 \mathrm{mg} / 1$ [12, 16]. High concentration of lead in drinking water causes cancer, interferes with vitamin D metabolism, affect mental development in children, toxic to the central and peripheral nervous systems.

\section{Conclusions}

An effective groundwater management and quality assessment cannot be made without a comprehensive knowledge of the groundwater chemistry, geology and hydrogeology of the catchment. Petrographic studies revealed that the parent rocks which are granites, rhyolites and sandstone contain some trace elements, galena-chalcopyrite-sphalerite mineralization and fluorde-rich minerals. The study has effectively shown that the composition of groundwater is in Zango, North-west Nigeria is a function of the bedrock/lithologic environment. During weathering processes these metals and minerals are released and are leached downward through infiltration thereby contaminating the groundwater system in the area.

Due to the fact that there is no industry in Zango and environs presently, the observed high elemental and fluoride concentration in the groundwater system in the area is purely a natural background concentration from processes such as weathering and dissolution. The study further established that heavy metal and fluoride concentration in groundwater in the area are higher in dry season than in rainy season and this may be attributed to the dilution effect of rainfall.

The government should provide tap water or drill deeper boreholes in the area to replace the shallow hand-dug well.

\section{Acknowledgements}

The authors are grateful to Prof. P. I. Olasehinde for his support and encouragement during the research period. 


\section{REFERENCES}

[1] Abimbola, A. F., Odukoya, A. M. and Olatunji, A. S., (2002). Influence of bedrock on the Hydrochemical characteristics of groundwater in Northern part of Ibadan metropolis, South-west Nigeria, Water resources, 13, 1-6.

[2] Amadi, A.N., Olasehinde, P.I., Okosun, E.A., and Yisa, J. (2011). Assessment of the Water Quality Index of Otamiri and Oraminukwa Rivers. Physics International, 1(2), 116-123.

[3] Amadi, A.N., Olasehinde, P.I., Okosun, E.A., Okoye, N.O., Okunlola, I.A., Alkali, Y.B.and Dan-Hassan, M. A. (2012). A Comparative Study on the Impact of Avu and Ihie Dumpsites on Soil Quality in Southeastern Nigeria. American Journal of Chemistry, 2(1):17-23.

[4] Amadi, A.N., Olasehinde, P.I., Yisa, J., Okosun, E.A., Nwankwoala, H.O.and Alkali, Y. B. (2013). Geostatistical Assessment of Groundwater Quality from Coastal Aquifers of Eastern Niger Delta, Nigeria. Geosciences, 2(3); 51-59.

[5] Aminu, T. and Amadi A. N., (2014). Fluoride Contamination of shallow Groundwater in parts of Zango Local Government Area of Katsina State, Northwest Nigeria. Journal of Geosciences and Geomatics, 2(4), 178-184.

[6] APHA. (1998). Standard methods for examination of water and waste water. Publisher: APHA-AWWA-WPCF.

[7] Chae, G.T, Seong, T.M., Kim, Bernhard, K., Kyoung-Ho, K. and Seong-Yong, K., (2007). Fluorine geochemistry in bedrock groundwater in the water-rock interaction and hydrologic mixing in Pocheon SPA area, South Korea, Total
Environment, 385(1-3), 272-283.

[8] Chidambaram S, Ramnathan A.L, and Vasudevan S., (2003). Fluoride removal studies in water using natural materilas. Water SA., 29(3):339-343.

[9] Dan-Hassan, M.A., Olasehinde, P.I., Amadi, A.N., Yisa, J. and Jacob, J.O., (2012). Spatial and Temporal Distribution of Nitrate Pollution in Groundwater of Abuja, Nigeria. International Journal of Chemistry 4(3), 39-48.

[10] EPA, (2001). National standard for drinking water. United States Environment Protection Agency, 816-F-02-013.

[11] National Census, (2006). The population of Zango Local Government Area of Katsina State, Northwest Nigeria. Unpublished report.

[12] NSDWQ, (2007). Nigerian Standard for Drinking Water Quality. Nigerian Industrial Standard, NIS:554, pp. 13-14.

[13] NMA, (2013). Meteorological data for Katsina State. Unpublished report from Nigerian Meteorological Agency.

[14] Schroll, E., (1976). Analytsche Geochemie, Band I, Metodik. Ferdinand Enke Verlag, Stuttgart. Pp 8-11.

[15] United States Environmental Protection Agency (1997). National Hardrock Mining Framework, 833, 97-103.

[16] World Health Organization, (2004). Guidelines for Drinking-Water Quality. Third Edition Incorporating the First and Second Addenda. Vol. 1. Recommendations.

[17] World Health Organisation, (2006). Guideline for Drinking Water Quality (Ed.) Geneva 